\title{
In-vitro progesterone production by ovarian interstitial cells from hypophysectomized hamsters*
}

\author{
S. L. Silavin and G. S. Greenwald \\ Department of Physiology, Ralph L. Smith Research Center, University of Kansas Medical \\ Center, Kansas City, Kansas 66103, U.S.A.
}

\begin{abstract}
Summary. Collagenase-dispersed interstitial cells from 5-day hypophysectomized hamsters produced progesterone $(81 \pm 7 \mathrm{pg} / 10000$ viable cells $/ 2 \mathrm{~h}$ incubation) and responded to ovine LH stimulation in vitro with a dose-dependent increase in progesterone. FSH and prolactin had no effect. The interstitial cells did not produce detectable levels of oestradiol, oestrone, androstenedione, 17 $\alpha$-hydroxyprogesterone or 20a-dihydroprogesterone although $17 \alpha$-hydroxyprogesterone production rose to $26 \pm 5 \mathrm{pg} / 10000$ cells $/ 2 \mathrm{~h}$ in response to $25 \mathrm{ng} \mathrm{LH} / \mathrm{ml}$. Isoproterenol $(500 \mathrm{ng} / \mathrm{ml})$ and epinephrine $(500 \mathrm{ng} / \mathrm{ml})$ stimulated progesterone production and this response was blocked by concurrent administration of $6 \times 10^{-6} \mathrm{M}$-propanolol which had no effect on LH-stimulated progesterone production. Simultaneous LH and catecholamine stimulation did not produce an additive effect. Incubation in medium containing $10 \%$ serum from hypophysectomized animals did not affect progesterone production. The addition of $10^{-6} \mathrm{M}$-D-ala ${ }^{6}$-LHRH to interstitial cells resulted in a significant reduction of baseline steroidogenesis. These results suggest long-term retention of functional LH receptors and integrity of the steroidogenic pathway through progesterone despite chronic gonadotrophin deprivation and may indicate a role for the interstitium in priming follicular growth following periods of anoestrus.
\end{abstract}

\section{Introduction}

Ovaries from hamsters hypophysectomized for as long as 20 days produce progesterone in vitro although serum progesterone concentrations are very low $(\leq 500 \mathrm{pg} / \mathrm{ml})$. Administration of $\mathbf{L H}$ in vivo increases progesterone production by ovaries in vitro (Taya \& Greenwald, 1980). The presence of $\Delta^{5}-3 \beta$-hydroxysteroid dehydrogenase was demonstrated histochemically only in the ovarian interstitium of long-term hypophysectomized hamsters (Taya, Saidapur \& Greenwald, 1980). Interstitial cells contain lipid droplets indicating the presence of steroid precursor (Taya et al., 1980). These data suggest that the interstitium is the site of steroid synthesis in hypophysectomized animals.

The low steroid production in vivo by the interstitium of hypophysectomized hamsters may be due to the presence of a circulating inhibitor that is normally suppressed by gonadotrophins (Taya \& Greenwald, 1980). Since gonadotrophin releasing hormone ( $\mathrm{GnRH})$ has been shown to inhibit steroidogenesis in rat granulosa cells (Hsueh \& Ling, 1979), porcine granulosa cells (Massicotte, Veilleux, Lovoie \& Labrie, 1980) and rat luteal cells (Clayton, Harwood \& Catt, 1979), it is possible that GnRH or a GnRH-like factor is responsible for the suppression of

* Reprint requests to Dr G. S. Greenwald. 
progesterone production in vivo in hypophysectomized hamsters. It is also possible that the interstitium is producing hormone that is rapidly converted to metabolites (Taya \& Greenwald, 1980 ) and we have found significant concentrations of 17 $\alpha$-hydroxyprogesterone and $20 a$-dihydroprogesterone in ovary and serum of hamsters during the oestrous cycle (Hubbard \& Greenwald, 1982) and pregnancy (Shaha \& Greenwald, 1982).

In the rat and the guinea-pig there is extensive adrenergic innervation of the interstitium (Burden, 1972) and catecholamines stimulate luteal progesterone production in the sheep (Jordan, Caffrey \& Niswender, 1978) and cow (Condon \& Black, 1976). It is therefore feasible that catecholamines modulate interstitial cell steroidogenesis. The present study was designed to examine further the steroidogenic capabilities of ovarian interstitial cells from hypophysectomized hamsters.

\section{Materials and Methods}

Golden hamsters (Mesocricetus auratus) were maintained on a $14 \mathrm{~h}$ light: $10 \mathrm{~h}$ dark schedule with lights on from 05:00 to 19:00 h. At least 3 consecutive 4-day cycles were monitored before using the animals.

Hamsters were hypophysectomized between $09: 00$ and 11:00 h on Day 1 of the oestrous cycle (day of ovulation) by the parapharyngeal approach under ketamine anaesthesia (Ketaject: Bristol Laboratories, Syracuse, New York). At necropsy, the sella turcica was examined with a dissecting microscope for fragments of pituitary and animals in which any gross remnants were present were rejected. Hamsters were decapitated at 09:00 h on Days 5-7 after hypophysectomy and trunk blood was saved for steroid hormone determinations.

\section{Interstitial cell preparation}

Ovaries were excised immediately, placed in Hank's balanced salts solution pH 7.4 (Parker, 1961) containing $25 \mathrm{~mm}$-Hepes (Sigma, St Louis, Missouri) at room temperature and trimmed of fatty tissue. Two to six ovaries were minced, placed in a $10 \mathrm{ml}$ flask containing $5 \mathrm{mg}$ collagenase $/ \mathrm{ml}$ (Type V, 205 i.u./mg, Sigma) in a total volume of $2 \mathrm{ml}$ medium and incubated in a Dubnoff metabolic incubator at $37^{\circ} \mathrm{C}$ with shaking. After $30 \mathrm{~min}$, fresh enzyme was added to the tissue and incubation continued for 1.5 to $2 \mathrm{~h}$ with intermittent aspiration of tissue through a Pasteur pipette to facilitate dispersion of cells. Cells were washed twice in medium and centrifuged at room temperature for $7 \mathrm{~min}$ at $50 \mathrm{~g}$. Cells were counted in a haemocytometer and cell viability was assessed by the trypan blue dye exclusion method. Approximately $75000-100000$ viable interstitial cells (see 'Discussion') were incubated in a total volume of 1 $\mathrm{ml}$ Hank's medium and treated as described below. After incubation at $37^{\circ} \mathrm{C}$ for $2 \mathrm{~h}$, tubes were snap-frozen in a solid $\mathrm{CO}_{2}$-ethanol bath and stored at $-20^{\circ} \mathrm{C}$ until further use. Before steroid determinations, tubes were thawed and the contents were sonicated for $5 \mathrm{sec}$ with a Kontes microultrasonic cell disruptor at a setting of $313 \mathrm{~W} / 6.45 \mathrm{~cm}^{2}$.

\section{Effects of gonadotrophin administration}

Interstitial cells were incubated for $2 \mathrm{~h}$ with various concentrations of ovine $\mathrm{LH}$ (NIAMDD-oLH-22), ovine FSH (NIAMDD-oFSH-13) or ovine prolactin (NIAMDD-oP-11). Progesterone determinations were made in all experiments and in some experiments oestrone, oestradiol, androstenedione, 17a-hydroxyprogesterone or 20a-dihydroprogesterone were measured.

\section{Roles of protein synthesis and microfilaments}

To determine whether progesterone production represented de-novo synthesis of steroid, interstitial cells were incubated with $10^{-4} \mathrm{M}$-cycloheximide (Sigma), a protein synthesis inhibitor, 
with or without $\mathrm{LH}(25 \mathrm{ng} / \mathrm{ml}$ ). In addition, 10 or $20 \mu \mathrm{g}$ cytochalasin $\mathrm{B} / \mathrm{ml}$ (purified from Helminthosporium dermatioideum (Sigma)), a microfilament function inhibitor, were added in $0.5 \%$ dimethylsulphoxide final concentration to assess the role of microfilaments in progesterone production.

\section{Effects of catecholamines, serum, and GnRH}

Cells were incubated with $500 \mathrm{ng}$ epinephrine/ml (Parke-Davis, Detroit, Michigan) or 500 $\mathrm{ng}$ isoproterenol/ml (Elkins-Sinn Inc., Cherry Hills, New Jersey) alone or in combination with $25 \mathrm{ng} \mathrm{LH} / \mathrm{ml}$ or $6 \times 10^{-6} \mathrm{M}$-propranolol (Inderal: Ayerst Laboratories, New York), a $\beta$-adrenergic antagonist.

The presence of a serum inhibitor of steroidogenesis was examined by incubating interstitial cells in medium containing $10 \%$ serum from hypophysectomized hamsters. Serum was previously pooled and was extracted 3 times with charcoal, heat treated at $50^{\circ} \mathrm{C}$ for $1 \mathrm{~h}$, charcoal extracted and heat treated, or untreated.

The antisteroidogenic properties of GnRH on the interstitial cells were examined by adding GnRH (Beckman Instrument Co., Bioproducts Div., Palo Alto, California) or D-ala ${ }^{6}$-LHRH (Vega Biochemicals, Tuscon, Arizona), an analogue of GnRH that has approximately 36 times the ability of $\mathrm{GnRH}$ to release LH (Banik \& Givner, 1975).

In one experiment, control or hypophysectomized hamsters received $400 \mathrm{ng}$ GnRH i.p. 30 min before decapitation to verify the biological activity of the GnRH and as another means of establishing the completeness of hypophysectomy.

\section{Radioimmunoassays ( $R I A)$}

Steroids. The antisera used in the assays were for progesterone (Surve, Bacso, Brinkerhoff \& Kirsch, 1976), androstenedione (provided by Dr J. Resko, Oregon Regional Primate Research Center, Beaverton, Oregon), oestrone (Wright, Collins \& Preedy, 1973), oestradiol (Wright et al., 1973), 17a-hydroxyprogesterone (Steranti Research Ltd, Hertfordshire, England) and 20adihydroprogesterone (provided by Dr C. N. Pang \& Dr J. Hilliard, University of California at Los Angeles). The radioimmunoassay procedures were identical to those described previously (Terranova, Connor \& Greenwald, 1978; Johnson, 1979). Sensitivities of the assays were $5 \mathrm{pg}$ for progesterone, 17 $\alpha$-hydroxyprogesterone and 20a-dihydroprogesterone, $4 \mathrm{pg}$ for androstenedione and $2 \mathrm{pg}$ for oestrone and oestradiol. Cross-reactivities for $17 a$ hydroxyprogesterone did not exceed $1 \%$ for all steroids analysed (Steranti Research Ltd). The inter-assay and intra-assay coefficients of variation for steroid assays were all $<7.0 \%$.

$L H$. LH was determined by using the NIAMDD kit. The method used was that of Bast \& Greenwald (1974) and the antiserum was anti-rat LH serum 3. The reference preparation used for standards was rat LH-RP-1 $(0.03 \times$ NIH-LH-S1). The iodination preparation was LH-I-6. The assay sensitivity was $350 \mathrm{pg}$ and the intra- and inter-assay coefficients of variation were 5.33 and $9.33 \%$ respectively.

\section{Statistics}

Specific differences were determined by Duncan's Multiple Range test (Steel \& Torrie, 1960) following one-way analysis of variance. Differences were adjudged significant if $P<0.05$.

\section{Effect of gonadotrophins}

\section{Results}

Collagenase-dispersed interstitial cells were $85 \pm 1.2 \%$ (mean \pm s.e.m., $n=12$ ) viable before incubation and $69.6 \pm 1.2 \%$ (mean \pm s.e.m., $n=5$ ) viable following a $2 \mathrm{~h}$ incubation. Steroid 
values are expressed as $\mathrm{pg} / 10000$ viable cells based on preincubation viability estimates. Interstitial cells produced baseline progesterone values of $81 \pm 7 \mathrm{pg} / 10000$ viable cells $/ 2 \mathrm{~h}$ and there were no detectable amounts of oestradiol, oestrone or androstenedione. Serum concentrations of 17a-hydroxyprogesterone were undetectable; baseline levels of $17 \alpha$ hydroxyprogesterone from interstitial cells were undetectable but rose to $26 \pm 5 \mathrm{pg} / 10000$ cells/ $2 \mathrm{~h}$ in response to $25 \mathrm{ng} \mathrm{LH} / \mathrm{ml}$. Concentrations of $20 \alpha$-dihydroprogesterone were undetectable in serum or interstitial cells from hypophysectomized hamsters.

Interstitial cells responded to LH stimulation in vitro with a dose-dependent increase in progesterone values which remained level at $100 \mathrm{ng} \mathrm{LH} / \mathrm{ml}$ (Table 1). Neither FSH (200 or 1000 $\mathrm{ng} / \mathrm{ml})$ nor prolactin $(125$ or $250 \mu \mathrm{g} / \mathrm{ml})$ stimulated steroid production by interstitial cells in vitro.

Table 1. Effect of LH on in-vitro progesterone production by interstitial cells from hypophysectomized hamsters

\begin{tabular}{lc}
\hline Treatment & Progesterone $(\mathrm{pg} / 10000$ cells $/ 2 \mathrm{~h})$ \\
\hline None & $81 \pm 7(6)$ \\
$1 \mathrm{ng} \mathrm{LH}$ & $160 \pm 12(5)$ \\
$10 \mathrm{ng} \mathrm{LH}$ & $367 \pm 18^{*}(6)$ \\
$25 \mathrm{ng} \mathrm{LH}$ & $562 \pm 67^{*}(6)$ \\
$100 \mathrm{ng} \mathrm{LH}$ & $2252 \pm 292^{*}(3)$ \\
$200 \mathrm{ng} \mathrm{LH}$ & $2417 \pm 292^{*}(3)$ \\
\hline
\end{tabular}

Values are mean \pm s.e.m. with the no. of observations in parentheses.

* Significantly different from control value, $P<0.05$.

\section{Role of protein synthesis and microfilaments}

The addition of $10^{-4} \mathrm{M}$-cycloheximide slightly reduced baseline progesterone values and completely blocked LH-induced progesterone secretion (Table 2). Cytochalasin B treatment had no effect on baseline production but significantly reduced $\mathrm{LH}$-stimulated progesterone secretion (Table 3).

Table 2. Effect of cycloheximide and LH on in-vitro progesterone production by interstitial cells from hypophysectomized hamsters

\begin{tabular}{lc}
\hline \multicolumn{1}{c}{ Treatment } & Progesterone (pg/10 000 cells/2 h) \\
\hline None & $81 \pm 7(6)$ \\
$25 \mathrm{ng} \mathrm{LH}$ & $562 \pm 67^{*}(6)$ \\
$10^{-4} \mathrm{M}$-cycloheximide & $45 \pm 16(5)$ \\
$10^{-4} \mathrm{M}$-cycloheximide $+25 \mathrm{ng} \mathrm{LH}$ & $55 \pm 10(6)$ \\
\hline
\end{tabular}

Values are mean \pm s.e.m. with the no. of observations in parentheses.

* Significantly different from control value, $P<0.05$.

\section{Effects of catecholamines, serum and GnRH}

Epinephrine and isoproterenol increased progesterone production (Table 4). Propranolol at $6 \times 10^{-6} \mathrm{M}$, a dose that inhibits catecholamine action without anaesthetizing membrane effects (Jordan et al., 1978), blocked the response of interstitial cells to epinephrine and isoproterenol but had no effect on LH-induced progesterone production (Table 4). Simultaneous administration of catecholamines and $\mathrm{LH}$ did not produce an additive increase in progesterone 
Table 3. Effect of cytochalasin B and LH on in-vitro progesterone production by interstitial cells from hypophysectomized hamsters

\begin{tabular}{clc}
\hline Group & \multicolumn{1}{c}{ Treatment } & Progesterone $(\mathrm{pg} / 10000$ cells $/ 2 \mathrm{~h})$ \\
\hline 1 & None & $60 \pm 16(6)$ \\
2 & $25 \mathrm{ng} \mathrm{LH}$ & $453 \pm 43^{\mathrm{a}}(5)$ \\
3 & $10 \mu \mathrm{g}$ cytochalasin B & $59 \pm 2(3)$ \\
4 & $20 \mu \mathrm{g}$ cytochalasin B & $43 \pm 1(5)$ \\
5 & $10 \mu \mathrm{g}$ cytochalasin B $+25 \mathrm{ng} \mathrm{LH}$ & $192 \pm 10^{\mathrm{b}}(5)$ \\
6 & $20 \mu \mathrm{g}$ cytochalasin B + 25 ng LH & $139 \pm 22^{\mathrm{b}}(6)$ \\
\hline
\end{tabular}

Values are mean \pm s.e.m. with the no. of observations in parentheses.

${ }^{a}$ Significantly different from values for all other groups, $P<0.05$.

${ }^{\mathrm{b}}$ Significantly different from control value, $P<0.05$.

Table 4. Effect of catecholamines and $\mathrm{LH}$ on in-vitro progesterone production by untreated or propranolol-treated interstitial cells from hypophysectomized hamsters

\begin{tabular}{clc}
\hline Group & \multicolumn{1}{c}{ Treatment } & Progesterone $(\mathrm{pg} / 10000$ cells $/ 2 \mathrm{~h})$ \\
\hline 1 & None & $57 \pm 14(6)$ \\
2 & 25 ng LH & $568 \pm 59^{\mathrm{a}}(6)$ \\
3 & $500 \mathrm{ng}$ epinephrine & $415 \pm 26^{\mathrm{b}}(6)$ \\
4 & $500 \mathrm{ng}$ isoproterenol & $540 \pm 37^{\mathrm{a}}(6)$ \\
5 & $6 \times 10^{-6}$ M-propranolol & $54 \pm 8(6)$ \\
6 & LH + epinephrine & $574 \pm 23^{\mathrm{a}}(6)$ \\
7 & LH + isoproterenol & $562 \pm 20^{\mathrm{a}}(6)$ \\
8 & LH + propranolol & $650 \pm 50^{\mathrm{a}}(6)$ \\
9 & Epinephrine + propranolol & $53 \pm 8(6)$ \\
10 & Isoproterenol + propranolol & $42 \pm 5(5)$ \\
\hline
\end{tabular}

Values are mean \pm s.e.m. with the no. of observations in parentheses.

"Significantly different from values for Groups $1,3,5,9$ and $10, P<0.05$.

${ }^{b}$ Significantly different from control value, $P<0.05$.

secretion, indicating that both substances were stimulating progesterone production by the same mechanism in the same cell type.

The addition of untreated, charcoal-extracted, heat-treated or charcoal extracted-heat treated serum from hypophysectomized hamsters had no effect on baseline or LH-induced progesterone production. Only the addition of $10^{-6} \mathrm{M}-\mathrm{D}-\mathrm{ala}{ }^{6}-\mathrm{LHRH}$ significantly reduced the baseline levels of progesterone (Table 5).

Table 5. Effect of GnRH and D-ala - LHRH on in-vitro progesterone production by interstitial cells of hypophysectomized hamsters

\begin{tabular}{lc}
\hline \multicolumn{1}{c}{ Treatment } & Progesterone $(\mathrm{pg} / 10000$ cells $/ 2 \mathrm{~h})$ \\
\hline None (control) & $45 \pm 7(8)$ \\
$10^{-6} \mathrm{M}-$ GnRH & $51 \pm 6(6)$ \\
$10^{-7} \mathrm{M}-$ GnRH & $40 \pm 7(7)$ \\
$10^{-6}$ M-D-ala - LHRH & $25 \pm 1^{*}(5)$ \\
$10^{-7}$ M-D-ala - LHRH & $52 \pm 7(6)$ \\
\hline
\end{tabular}

Values are mean \pm s.e.m. with the no. of observations in parentheses.

* Significantly different from control value, $P<0.05$. 
Treatment of hypophysectomized hamsters with $400 \mathrm{ng}$ GnRH $30 \mathrm{~min}$ before killing had no effect on interstitial cell steroidogenesis or serum progesterone concentrations $(<1 \mathrm{ng} / \mathrm{ml})$. In addition, serum LH concentrations were undetectable. Injection of $400 \mathrm{ng} \mathrm{GnRH}$ to intact hamsters on the morning of Day 1, $30 \mathrm{~min}$ before decapitation, resulted in serum LH concentrations of $144 \cdot 3 \pm 26 \cdot 2 \mathrm{ng} / \mathrm{ml}(14 \cdot 3 \pm 2.5 \mathrm{ng} / \mathrm{ml}$ for intact control animals).

\section{Discussion}

Although the interstitial cell preparations used in these experiments were not highly purified, several lines of evidence support the contention that progesterone is produced by interstitial cells and not by contaminating follicular cells. Corpora lutea are not maintained following hypophysectomy in the hamster. Histochemical studies demonstrated that by Day 6 after hypophysectomy, only the interstitium contained $\Delta^{5}-3 \beta$-hydroxysteroid dehydrogenase; the enzyme was lacking from the small preantral follicles (Taya et al., 1980). Finally, ${ }^{125} \mathrm{I}$-labelled hCG binds only to interstitial cells and theca in ovaries from cyclic hamsters and not to granulosa cells of preantral follicles (Oxberry, 1981).

Although $25 \mathrm{ng} \mathrm{LH}$ did not produce maximal progesterone production by interstitial cells, this dose was used in these studies because it consistently resulted in at least a 7 -fold increase in progesterone production and allowed for the determination of possible additive effects of $\mathrm{LH}$ and catecholamines.

It was possible that progesterone was produced by hypophysectomized hamsters but was rapidly converted to metabolites. The progestagen, 17a-hydroxyprogesterone represents a steroidogenic endpoint in the hamster ovary similar to that of $20 \alpha$-dihydroprogesterone in the rat (Hubbard \& Greenwald, 1982). Thus, if progesterone produced by interstitial cells was being converted in vivo, 17a-hydroxyprogesterone would be a likely end product. However, 17a-hydroxyprogesterone and 20a-dihydroprogesterone were undetectable in serum of hypophysectomized hamsters. Our study shows that interstitial cells from hypophysectomized hamsters produce 17 $\alpha$-hydroxyprogesterone only in response to $\mathrm{LH}$ and indicates that progesterone is not produced in vivo and metabolized. However, other metabolites of progesterone could have been involved.

The addition of serum from hypophysectomized hamsters to incubations of interstitial cells had no effect on progesterone synthesis indicating a lack of circulating inhibitor of steroidogenesis in the hypophysectomized animal. However, D-ala ${ }^{6}$-LHRH did effectively inhibit baseline progesterone production (Table 5). While serum concentrations of $\mathrm{GnRH}$ are not great enough to cause an inhibition of progesterone production in vivo it is possible that a local GnRH-like factor is present in preantral follicles or uterus. A uterine factor may also involve one or more prostaglandins.

The necessity of protein synthesis for trophic hormone stimulation of steroidogenesis has been documented for rat adrenal (Davis \& Garren, 1968), rat ovaries (Azhar, Menon \& Menon, 1980) and ovine corpora lutea (Silavin, 1979). The interstitial cells of hypophysectomized hamsters therefore appear to require protein synthesis in order to produce progesterone in response to LH in the same manner as do other steroidogenic tissues.

Microfilaments appear to be important cellular elements in trophic hormone stimulation of steroidogenesis. There is evidence suggesting a role for microfilaments in transport of cholesterol to mitochondria in steroidogenic tissue, including ovine corpus luteum (Silavin, Moss \& Niswender, 1980), rat luteal cells (Azhar \& Menon, 1981) and adrenal tumour cells (Mrotek \& Hall, 1977). Cytochalasin B inhibits trophic hormone stimulation of steroidogenesis without affecting baseline steroid production and blocks LH-induced progesterone production in hamster interstitial cells, indicating a role for microfilaments in the steroidogenesis of these cells.

Catecholamines stimulated progesterone production in interstitial cells and propranolol 
blocked this effect without affecting LH-induced progesterone production (Table 4). The effects of $\mathrm{LH}$ and catecholamines were not additive, suggesting that both substances stimulate steroidogenesis via the same mechanism and, in addition to retention of LH binding sites, adrenergic receptors are also retained in the interstitium of the long-term hypophysectomized hamster. The presence of adrenergic innervation of the interstitium has been shown in the rat and guinea-pig (Burden, 1972). It is unclear what role catecholamines may play alone or in combination with gonadotrophins in interstitial cell steroidogenesis during the cycle or pregnancy.

Interstitial cells have morphological and steroidogenic properties similar to those of other steroid-producing cells except that they retain the gonadotrophin receptor-adenylate cyclase mechanism and steroidogenic enzymes for long periods despite lack of gonadotrophin. These characteristics may be of particular importance to animals that are seasonal breeders and whose ovaries become quiescent during the non-breeding season or hibernation. In bats, the first ovarian event to occur before the end of hibernation is hypertrophy of interstitial cells (Oxberry, 1979). Similarly, administration of PMSG to hypophysectomized rats leads to interstitial cell hypertrophy (Carithers \& Green, 1972), suggesting increased activity of the interstitial gland. Thus, the ability of interstitial cells to produce steroid after gonadotrophin deprivation may be necessary to 'prime' follicular growth in the ovary at the onset of the breeding season.

This research was supported by a grant from NIH (HD00596). We thank NIAMDD for the LH radioimmunoassay kits and for the ovine peptide hormones.

\section{References}

Azhar, S. \& Menon, K.M.J. (1981) Receptor-mediated gonadotropin action in the ovary. Action of cytoskeletal element-disrupting agents on gonadotropin-induced steroidogenesis in rat luteal cells. Biochem. J. 194, 19-27.

Azhar, S., Menon, M. \& Menon, K.M.J. (1980) Receptor mediated gonadotropin action in the ovary. Modulation of progesterone response in isolated rat ovarian cells by gonadotropin, cholera enterotoxin and cyclic nucleotides: requirement for RNA and protein synthesis. Acta endocr., Copenh. 95, 528539.

Banik, U.K. \& Givner, M.L. (1975) Ovulation induction and antifertility effects of an LHRH analogue (AY-25,205) in cyclic rats. J. Reprod. Fert. 44, 87-89.

Bast, J.D. \& Greenwald, G.S. (1974) Serum profiles of follicle stimulating hormone, luteinizing hormone and prolactin during the estrous cycle of the hamster. Endocrinology 94, 1295-1299.

Burden, H.W. (1972) Adrenergic innervation in ovaries of the rat and guinea-pig. Am.J.Anat. 133, 455-462.

Carithers, J.R. \& Green, J.A. (1972) Ultrastructure of rat ovarian interstitial cells. II. Response to gonadotropin. J. Ultrastruct. Res. 39, 251-261.

Clayton, R.N., Harwood, J.P. \& Catt, K.J. (1979) Gonadotrophin-releasing hormone analogue binds to luteal cells and inhibits progesterone production. Nature, Lond. 282, 90-92.

Condon, W.A. \& Black, D.L. (1976) Catecholamineinduced stimulation of progesterone by the bovine - corpus luteum in vitro. Biol. Reprod. 15, 573-578.
Davis, W.W. \& Garren, L.D. (1968) On the mechanism of action of adrenocorticotropic hormone. The inhibitory site of cycloheximide in the pathway of steroid biosynthesis. J. biol. Chem. 243, 5153-5157.

Hsueh, A.J.W. \& Ling, N.C. (1979) Effect of an antagonistic analog of gonadotropin releasing hormone upon ovarian granulosa cell function. Life Sci. 25, 1223-1230.

Hubbard, C.J. \& Greenwald, G.S. (1982) Cyclic nucleotides, DNA, and steroid levels in ovarian follicles and corpora lutea of the cyclic hamster. Biol. Reprod. 26, 230-240.

Johnson, D.C. (1979) Maintenance of functional corpora lutea in androgenized female rats treated with PMSG. J. Reprod. Fert. 56, 263-269.

Jordan, A.W., Caffrey, J.L. \& Niswender, G.D. (1978) Catecholamine-induced stimulation of progesterone and adenosine $3^{\prime}, 5^{\prime}$-monophosphate production by dispersed ovine luteal cells. Endocrinology 103, 385-392.

Massicotte, J., Veilleux, R., Lovoie, M. \& Labrie, F. (1980) An LHRH agonist inhibits FSH-induced cyclic AMP accumulation and steroidogenesis in porcine granulosa cells in culture. Biochem. Biophys. Res. Commun. 94, 1362-1366.

Mrotek, J.J. \& Hall, P.F. (1977) Response of adrenal tumor cells to adrenocorticotropin: site of inhibition by cytochalasin B. Biochemistry, N.Y. 16, 31773181 .

Oxberry, B.A. (1979) The reproductive biology of the female vespertillionid bat, Antrozous pallidus. $\mathrm{PhD}$. dissertation, University of Arizona. 
Oxberry, B.A. (1981) Autoradiographic analysis of gonadotropin binding in the hamster ovary throughout the estrous cycle. Biol. Reprod. 24, Suppl. 1, p. 118a, Abstr. 192.

Parker, R.C. (1961) Methods of Tissue Culture, p. 57. Paul B. Hoeber, Inc., New York.

Shaha, C. \& Greenwald, G.S. (1982) In vivo and in vitro production of progestins by the corpus luteum of pregnancy of the hamster. Biol. Reprod. 26, 854-860.

Silavin, S.L. (1979) Regulation of steroidogenesis in the ovine corpus luteum. Ph.D. dissertation, Colorado State University, Fort Collins.

Silavin, S.L., Moss, G.E. \& Niswender, G.D. (1980) Regulation of steroidogenesis in the ovine corpus luteum. Steroids 36, 229-241.

Steel, R.G. \& Torrie, J.H. (1960) Principals and Procedures of Statistics. McGraw-Hill, New York.

Surve, A.H., Bacso, I., Brinkerhoff, J.H. \& Kirsch, S.J. (1976) Plasma levels of progesterone in pseudo- pregnant rabbits actively immunized with a progesterone protein conjugate. Biol. Reprod. 15, 343349.

Taya, K. \& Greenwald, G.S. (1980) In vitro and in vivo ovarian steroidogenesis in the long-term hypophysectomized hamster. Endocrinology 106, 1093-1098.

Taya, K., Saidapur, S.K. \& Greenwald, G.S. (1980) Interstitium: site of steroid synthesis in the ovary of the long-term hypophysectomized hamster. Biol. Reprod. 22, 307-318.

Terranova, P.F., Connor, J.S. \& Greenwald, G.S. (1978) In vitro steroidogenesis in corpora lutea and nonluteal ovarian tissues of the cyclic hamster. Biol. Reprod. 19, 249-255.

Wright, K., Collins, D.C. \& Preedy, J.R.K. (1973) Comparative specificity of antisera raised against estrone, estradiol-17 $\beta$ and estriol using 6-0carboxymethyloxine bovine serum albumin derivatives. Steroids 21, 755-769. 